\title{
Repair of oxidative DNA damage in Gram- positive bacteria: the Lactococcus lactis Fpg protein
}

\author{
Patrick Duwat, ${ }^{1}$ Regina de Oliveira, ${ }^{2}$ S. Dusko Ehrlich' \\ and Serge Boiteux ${ }^{2}$
}

Author for correspondence: Serge Boiteux. Tel: +33145 5964 05. Fax: +33146784120.

1 Laboratoire de Génétique Microbienne, Institut National de la Recherche Agronomique, Domaine de Vilvert, 78352 Jouy en Josas, France

2 Groupe 'Réparation des lésions radio et chimioinduites', Centre National de la Recherche Scientifique URA147, Institut Gustave-Roussy, 94800 Villejuif, France
The formamidopyrimidine DNA glycosylase gene (fpg-L) of the Gram-positive microaerophilic bacterium Lactococcus lactis subsp. cremoris ML3 has been cloned, characterized and sequenced. The fpg-L gene is composed of 819 bp encoding a protein of $31.3 \mathrm{kDa}$ (Fpg-L). The deduced amino acid sequence of the Fpg-L protein shows $59 \%$ similarity and $38 \%$ identity with the Escherichia coli Fpg protein (Fpg-E). Polyclonal antibodies against Fpg-E react with the Fpg-L protein. The Fpg-L protein was purified to apparent homogeneity from the overproducing E. coli strain BH410 hosting plasmid pVE1064, which carries fpg-L under the control of the $E$. coli lac promoter. In its active form, Fpg-L is a $30 \mathrm{kDa}$ monomeric enzyme with a measured isoelectric point of 9.0. It contains one zinc per molecule and has a zinc finger motif localized at the carboxyterminal end (Cys- $\left.\mathrm{X}_{\mathbf{2}}-\mathrm{Cys}-\mathrm{X}_{\mathbf{1 6}}-\mathrm{Cys}-\mathrm{X}_{\mathbf{2}}-\mathrm{Cys}-\mathrm{X}_{\mathbf{3}}-\mathrm{COOH}\right)$. The Fpg-L protein has two enzyme activities: DNA glycosylase, which excises 2,6-diamino-4-hydroxy-5Nmethylformamidopyrimidine and 7,8-dihydro-8-oxoguanine, and DNA nicking at abasic sites. Furthermore, the expression of the fpg-L gene in fpg and mut $Y$ mutants of $E$. coli suppresses their spontaneous GC $\rightarrow$ TA mutator phenotype. The similarity of the activity of the two Fpg proteins and its conservation in evolutionarily distant bacteria may reflect the importance of its role in protecting bacterial DNA against oxidative free radicals.

Keywords: Lactococcus lactis, DNA repair, oxidative DNA damage, Fpg protein, fpg gene

\section{INTRODUCTION}

Reactive oxygen-derived species (ROS) formed in cells either as a byproduct of aerobic metabolism or during oxidative stress have been suggested to play an important role in biological processes such as mutagenesis, carcinogenesis and ageing (Breimer, 1990; Ames et al., 1993; Boiteux, 1993). Amongst ROS, the hydroxyl radical $\left(\mathrm{OH}^{*}\right)$ is highly reactive and produces a complex pattern of DNA modifications (Dizdaroglu, 1991). To counteract the lethal and mutagenic effects of DNA damage induced by ROS, cells have developed DNA repair mechanisms (Sancar \& Myles, 1989). Both base excision repair and

\footnotetext{
Abbreviations: AP, apuriniclapyrimidinic; Fapy, 2,6-diamino-4-hydroxy$5 \mathrm{~N}$-methylformamidopyrimidine; Fpg-E protein, Fpg protein of Escherichia coli; Fpg-L protein, Fpg protein of Lactococcus lactis; FPLC, fast protein liquid chromatography; 8-OxOG, 7,8-dihydro-8-oxoguanine; $\mathrm{pBS}$, pBluescript $\mathrm{KS}(+)$; ROS, reactive oxygen-derived species.

The EMBLGenBank accession number for the nucleotide sequence of $f p g-L$ is $X 74298$.
}

nucleotide excision repair are involved in the removal of oxidized bases in DNA (Lin \& Sancar, 1989; Czeczot et al., 1991). In Escherichia coli, two DNA glycosylases excise oxidized bases, the pyrimidine-specific Nth protein (Breimer \& Lindahl, 1985; Dizdaroglu et al., 1993), and the purine-specific Fpg protein. In vitro, the E. coli Fpg protein (Fpg-E) releases 2,6-diamino-4-hydroxy-5Nmethylformamidopyrimidine (Fapy) and 7,8-dihydro-8oxoguanine (8-OxoG) residues (Chetsanga \& Lindahl, 1979; Breimer, 1984; Boiteux et al., 1984, 1992; Tchou et al., 1991 ; Castaing et al., 1993). Fpg-E also possesses two further activities: DNA incision at apurinic/apyrimidinic (AP) sites (Bailly et al., 1989; Boiteux et al., 1990b), and excision of terminal 5'-deoxyribose phosphate (Graves et al., 1992). In vivo, the Fpg-E protein repairs lethal and promutagenic oxidative DNA damage (Czeczot et al., 1991; Tudek et al., 1993). Furthermore, fpg (mutM) mutants of $E$. coli have a spontaneous GC $\rightarrow$ TA mutator phenotype (Michaels et al., 1992; Castaing et al., 1993) that is greatly enhanced when combined with mut $Y$ mutations (Michaels et al., 1992). These enzymes, Fpg and MutY, 
together with MutT form the $\mathrm{GO}$ system that prevents mutagenesis by oxidized guanine residues in DNA and in the nucleotide pool (Michaels \& Miller, 1992; Grollman \& Moriya, 1993).

Lactococcus lactis subsp. cremoris is a Gram-positive microaerophilic bacterium that has a $2300 \mathrm{~kb}$ genome with a $\mathrm{G}+\mathrm{C}$ content of $37 \mathrm{~mol} \%$ (LeBourgeois et al., 1992), and it is extensively used in the food industry. The amelioration of the dairy strains needs a molecular approach for solving industrial problems such as the recovery of growth after freezing, and the non-reproducibility of fermentations. Here, we report the molecular cloning and DNA sequencing of the $f p g$ gene ( $f p g-\mathrm{L})$, and the purification of the Fpg protein (Fpg-L) from $L$. lactis ML3. The results suggest that the $f p g-\mathrm{L}$ and the $f p g-\mathrm{E}$ genes have issued from a common ancestor. Furthermore, we show that Fpg protein has a highly conserved function in prokaryotic cells.

\section{METHODS}

Bacterial strains, plasmids and enzymes. E. coli strains used were TG1 and JM105 (Sambrook et al., 1989), BH410 (as
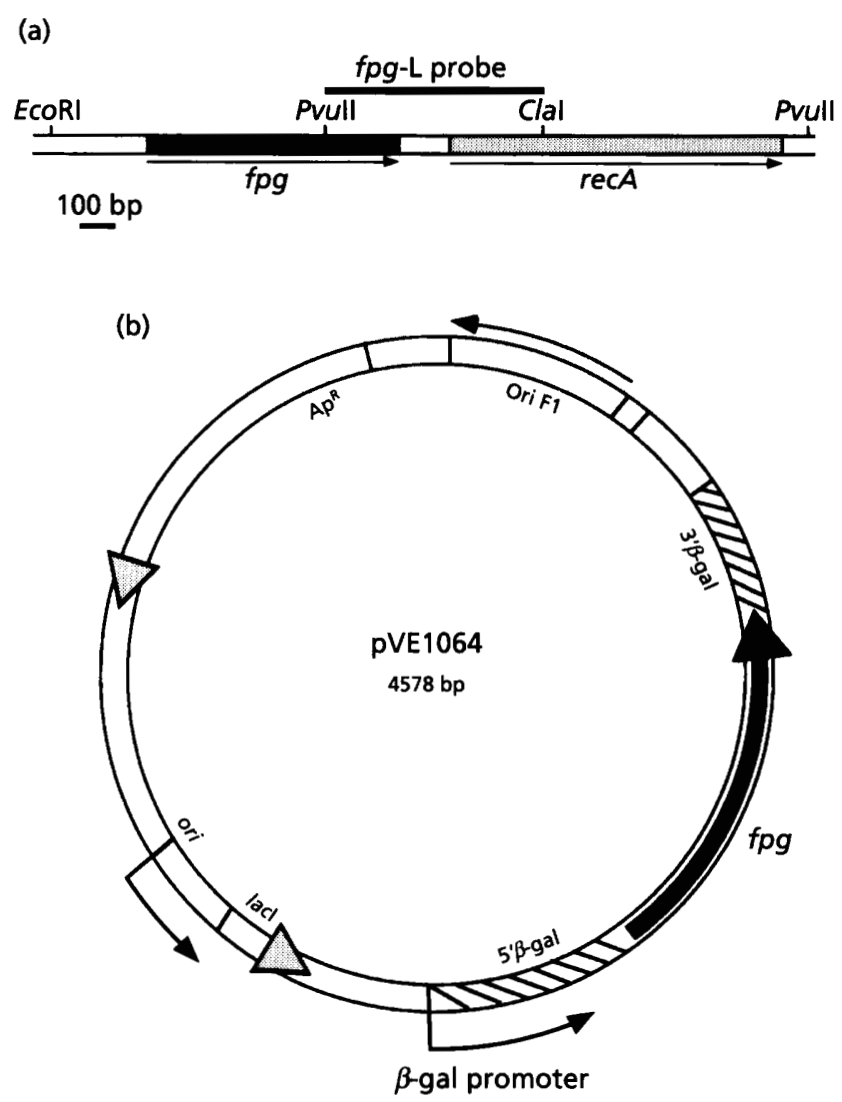

Fig. 1. Cloning of the fpg-L gene. (a) Physical map of the fpgrecA locus of $L$. lactis ML3. The arrows indicate the direction of transcription. Positions of the restriction endonuclease sites and the $550 \mathrm{bp}$ probe used to clone the $f p g-\mathrm{L}$ gene are indicated. (b) Physical map of pVE1064 containing the fpg-L gene. The black area corresponds to the $f p g-L$ gene, the hatched area to other lactococcal sequences. Other sequences are from the pBS plasmid vector.
JM105 but $f p g-1::$ kan $^{\mathbf{R}}$ ) (Boiteux \& Huisman, 1989; Tudek et al., 1993), CC104 [ara $\Delta($ gpt-lac $) 5\left(\mathrm{~F}^{\prime}\right.$ lacI378 lacZ461 pro $\left.\left.A^{+} B^{+}\right)\right]$ (Cupples \& Miller, 1989), PR70 [mic $A($ mut $\left.Y):: k a n^{\mathrm{R}}\right]$ (Radicella et al., 1988), BH540 (as CC104 but fpg-1), BH980 (as CC104 but mut $Y$ ) and $\mathrm{BH} 990$ (as CC104 but $f p g-1$ mut $Y$ ) (this study). E. coli strains were grown in LB broth at $37^{\circ} \mathrm{C}$, and genetic manipulations of bacteria were performed as described by Miller (1972). L. lactis ML3 strain ML3 (Duwat et al., 1992) was grown on M17 glucose medium (Terzaghi \& Sandine, 1975). The pBluescript $\mathrm{KS}(+)(\mathrm{pBS})$ plasmid was obtained from Stratagene. Plasmid pVE1001 is a derivative of $\mathrm{pBS}$ and contains the $L$. lactis $\operatorname{rec} A$ gene and, upstream, a truncated ORF that is homologous to that of the E. coli Fpg protein (Duwat et al., 1992). The Fpg-E protein was prepared as described previously (Boiteux et al., 1990b). Restriction enzymes, DNA polymerase, DNA ligase, T4 polynucleotide kinase were purchased from Boehringer Mannheim or Appligene, and used as recommended by the manufacturer.

Cloning and sequencing of the fpg-L gene. All DNA manipulations were performed according to published methods (Sambrook et al., 1989; Duwat et al., 1992). An L. lactis ML3 genomic library was constructed using purified EcoRI-ClaI DNA fragments of $1.5-2 \mathrm{~kb}$, blunted by phage T4 DNA polymerase and cloned into SmaI-linearized pBS. E. coli TG1 was transformed with the library and ampicillin-resistant transformants were colony hybridized using Hybond-N nylon membrane (Amersham). The probe used was a ${ }^{32} \mathrm{P}$-labelled 550 bp SpeI-ClaI DNA fragment of plasmid pVE1001 (see Fig. 1a). For DNA sequencing, different restriction fragments were subcloned from pVE1064. DNA sequences were determined on double-stranded DNA by the dideoxy chain-termination method. The sequence reported was determined on both strands.

Purification of the Fpg-L protein. LB broth $(5 \mathrm{l})$ containing $50 \mu \mathrm{g}$ ampicillin $\mathrm{ml}^{-1}$ was inoculated with $50 \mathrm{ml}$ of an overnight culture of E. coli BH410(pVE1064) plasmid. The cells were grown at $37^{\circ} \mathrm{C}$ until $\mathrm{OD}_{600} 1.0$ and supplemented with $0.5 \mathrm{mM}$ IPTG. The IPTG-induced culture was incubated at $37^{\circ} \mathrm{C}$ for $20 \mathrm{~h}$. The cells were harvested, washed and stored at $-70^{\circ} \mathrm{C}$. The bacteria $(13 \mathrm{~g})$ were lysed in buffer A $[50 \mathrm{mM}$ HEPES/KOH, pH 7.6, $1 \mathrm{mM} \mathrm{Na}{ }_{2}$ EDTA, $5 \mathrm{mM} \beta$-mercaptoethanol and $5 \%(\mathrm{v} / \mathrm{v})$ glycerol] containing $0.25 \mathrm{M} \mathrm{NaCl}$. The lysate was centrifuged at 30000 r.p.m. for $60 \mathrm{~min}$ at $2{ }^{\circ} \mathrm{C}$. The supernatant was the crude extract fraction (fraction $1,140 \mathrm{ml}$ ). Fraction 1 was loaded onto a QMA anion-exchange column (Waters ACELL, $75 \mathrm{ml}$ bed volume) equilibrated with buffer A containing $0.25 \mathrm{M} \mathrm{NaCl}$. The Fpg-L protein was not retained in these conditions (fraction $2,300 \mathrm{ml}$ ). Fraction 2 was dialysed against buffer A containing $50 \mathrm{mM} \mathrm{NaCl}$, applied to a phospho Ultrogel (PCU) cation-exchange column (IBF-LKB, $20 \mathrm{ml}$ bed volume). The active fractions eluted at $0.25 \mathrm{M} \mathrm{NaCl}$ (fraction 3 , $87 \mathrm{ml}$ ). Fraction 3 was precipitated with ammonium sulfate (500 $\mathrm{g} \mathrm{l}^{-1}$ ), resuspended in $7 \mathrm{ml}$ buffer $\mathrm{A}$ without glycerol but containing $1 \mathrm{M} \mathrm{NaCl}$, and loaded on a gel filtration column (IBF-LKB AcA54; $1.6 \times 150 \mathrm{~cm}$ ). The active fractions were pooled (fraction $4,36 \mathrm{ml}$ ). Fraction 4 was supplemented with ammonium sulfate to a final concentration of $0.85 \mathrm{M}$ and loaded onto a Phenyl Sepharose CL-4B column (Pharmacia, $10 \mathrm{ml}$ bed volume). The column was washed with buffer B $(50 \mathrm{mM}$ HEPES/KOH, pH 7·6, 1 mM, Na ${ }_{2}$ EDTA, 5 mM $\beta$-mercaptoethanol, $1 \mathrm{M} \mathrm{NaCl}$ and $0.85 \mathrm{M}$ ammonium sulfate), and eluted with a linear gradient $(0-100 \%$ buffer $A)$. The active fractions were pooled (fraction $5,16 \mathrm{ml}$ ). Fraction 5 was dialysed against buffer A containing $50 \mathrm{mM} \mathrm{NaCl}$, and loaded onto an FPLC cationic MonoS HR5/5 column (Pharmacia). The active fractions eluted at $0.3 \mathrm{M} \mathrm{NaCl}$ (fraction $6,9.5 \mathrm{ml}$ ). 
Inhibition of Fpg-E and Fpg-L by polyclonal antibodies against Fpg-E protein. Antibodies were prepared as described by Boiteux et al. (1990b) and affinity-purified from rabbit antisera using an Fpg-E protein Sepharose column. Five nanograms of purified Fpg-E or Fpg-L protein were incubated with anti-Fpg-E antibodies for $10 \mathrm{~min}$ at $20^{\circ} \mathrm{C}$ in assay buffer. Then $\left[{ }^{3} \mathrm{H}\right]$ Fapy-poly $(\mathrm{dG}-\mathrm{dC})$ substrate was added and the Fapy DNA glycosylase activity was measured as described.

Assay for the repair of 8-OxoG. A 34-mer oligonucleotide containing a single $8-\mathrm{OxoG}$ residue was used as substrate: 5'-GGCTTCATCGTTATT(8-OxoG)ATGACCTGGTGGATACCG $-5^{\prime *}$. The nucleotide at the $3^{\prime}$ end of this modified $34-$ mer was inverted, yielding the sequence $5^{\prime}-(\mathrm{N})_{33^{-}} 3^{\prime}-\mathrm{P}-3^{\prime}-\mathrm{N}-5^{\prime}$ (Castaing et al., 1993). Both ends of this 34-mer were acted on by the T4 polynucleotide kinase and $\left[\gamma_{-}{ }^{32} \mathrm{P}\right]$ ATP $\left[3000 \mathrm{Ci} \mathrm{mmol}{ }^{-1}\right.$ (111 TBq mmol ${ }^{-1}$ ), Amersham]. $5^{\prime}{ }^{32} \mathrm{P}$-labelling, assay conditions and PAGE analysis were as described previously (Castaing et al., 1993).

\section{RESULTS}

\section{Cloning of the fpg-L gene}

Sequence analysis of an $L$. lactis DNA fragment containing the $\operatorname{rec} A$ gene revealed, immediately upstream from $\operatorname{rec} A$, a truncated ORF which would encode a polypeptide having homology with the carboxy-terminal end of the E. coli Fpg protein (Boiteux et al., 1987; Duwat et al., 1992). This upstream DNA fragment was used as probe for restriction mapping and cloning of the $f p g-\mathrm{L}$ gene (Fig. 1a). Considering the size of the E. coli fpg gene (807 bp) and the location of the ClaI restriction site in the lactococcal $\operatorname{rec} A$ sequence, a $1.6 \mathrm{~kb}$ EcoRI-ClaI DNA fragment was expected to contain the entire $f p g$ - $\mathrm{L}$ gene (Fig. 1a). For cloning, L. lactis chromosomal DNA was digested with EcoRI and ClaI and DNA fragments from $1.5-2.0 \mathrm{~kb}$ were recovered, blunted with T4 DNA polymerase and ligated with the $S m a I$-linearized pBS vector. White ampicillin-resistant transformants were selected and colony hybridized. Plasmid DNA was extracted from colonies which gave a strong hybridization signal with the DNA probe used. Fig. 1(b) shows the physical map of $\mathrm{pVE} 1064$, which contains the $f p g$-L gene placed under the control of the E. coli lac promoter.

\section{Nucleotide sequence of the fpg-L gene}

The 1615 bp DNA fragment cloned in pVE1064 consists of a potential ORF of $819 \mathrm{bp}$ and the $5^{\prime}$ region of the lactococcal $\operatorname{rec} A$ gene (Fig. 1). The potential ORF codes for a protein of 273 amino acids with a molecular mass of $31.3 \mathrm{kDa}$. The putative protein coded by the $f p g$ - $\mathrm{L}$ gene shows $59 \%$ similarity and $38 \%$ identity with the Fpg-E protein. The sequence upstream of the $819 \mathrm{bp}$ ORF contains two potential RNA-polymerase-binding sites and a translation initiation site. The DNA sequence between positions 1 and 1158 will appear in the EMBL and GenBank database with the accession number X74298. The sequence from position 1159-1615 was published by Duwat $e$ al. (1992).

\section{Sequence comparison with the Fpg-L protein}

Database searches revealed four sequences with significant homology with the Fpg-L protein: the Fpg-E protein, an ORF of Bacillus firmus (Ivey, 1990), the amino-terminal portions of ORFs from Synechocystis sp. PCC 6803 (Chitnis et al., 1989) and Synechococcus sp. PCC 6301 (Rhiel \& Bryant, 1992) (Fig. 2). The amino-terminal part was reported for these four proteins and all possess an identical stretch of eight amino acids (PELPEVET) (Fig. 2). No functional role has been attributed to this region. In addition, the carboxy-terminal end of three of these proteins was determined and shows a zinc finger consensus sequence whose organization is conserved (Cys$\mathrm{X}_{2}$-Cys- $\mathrm{X}_{16}$-Cys- $\mathrm{X}_{2}$-Cys) (Fig. 2). In E. coli, the four cysteines in the zinc finger motif of the Fpg protein are important, since mutation in any of them results in proteins which are unable to bind DNA and catalyse enzymic reactions (O'Connor et al., 1992; Castaing et al., 1993).

\section{Overproduction and purification of the Fpg-L protein}

To overproduce the protein coded by $f p g$-L, plasmid pVE1064 was transformed into E. coli $\mathrm{BH} 410$ which has a disrupted chromosomal fpg gene (Boiteux \& Huisman, 1989). Without IPTG-induction of the lac promoter, a low level of Fapy DNA glycosylase activity was detected in BH410(pVE1064) crude extracts. Addition of IPTG to the culture derepresses the lac promoter and allows the level of Fapy DNA glycosylase activity to increase by more than 200-fold as compared with the uninduced level. These results show that the $f p g$ - $\mathrm{L}$ gene encodes an enzyme, the Fpg-L protein, endowed with Fapy DNA glycosylase activity.

Twelve milligrams of apparently homogeneous Fpg-L protein were prepared from $13 \mathrm{~g}$ IPTG-induced cells (Table 1). The final fraction appeared as a single protein band on SDS-PAGE with a molecular mass of about $30 \mathrm{kDa}$ (Fig. 3). A unique amino-terminal sequence was determined and the first 22 amino acids perfectly match the sequence deduced from the nucleotide sequence, confirming that $f p g-\mathrm{L}$ is the structural gene of the Fpg protein of $L$. lacits. The Fpg-L protein is basic, with a measured isoelectric point of $9 \cdot 0$. Atomic absorption spectroscopy analysis revealed, as expected, that there is one zinc per Fpg-L protein molecule.

\section{Polyclonal antibodies against the Fpg-E protein recognize Fpg-L protein}

Polyclonal antibodies against the Fpg-E protein inhibited the Fapy DNA glycosylase activity of the Fpg-L protein. However, a 10-20-fold excess of antibodies was required to inhibit Fpg-L activity as compared to the amount required to inhibit Fpg-E protein (Fig. 4).

\section{Fpg-L protein nicks DNA at AP sites and excises 8-OXOG}

The results reported above suggest a strong conservation between the Fpg-E and Fpg-L proteins. Several lines of evidence indicate that the Fpg-L protein is endowed with an AP nicking activity. Firstly, both the Fapy DNA glycosylase activity and an EDTA-resistant AP nicking 


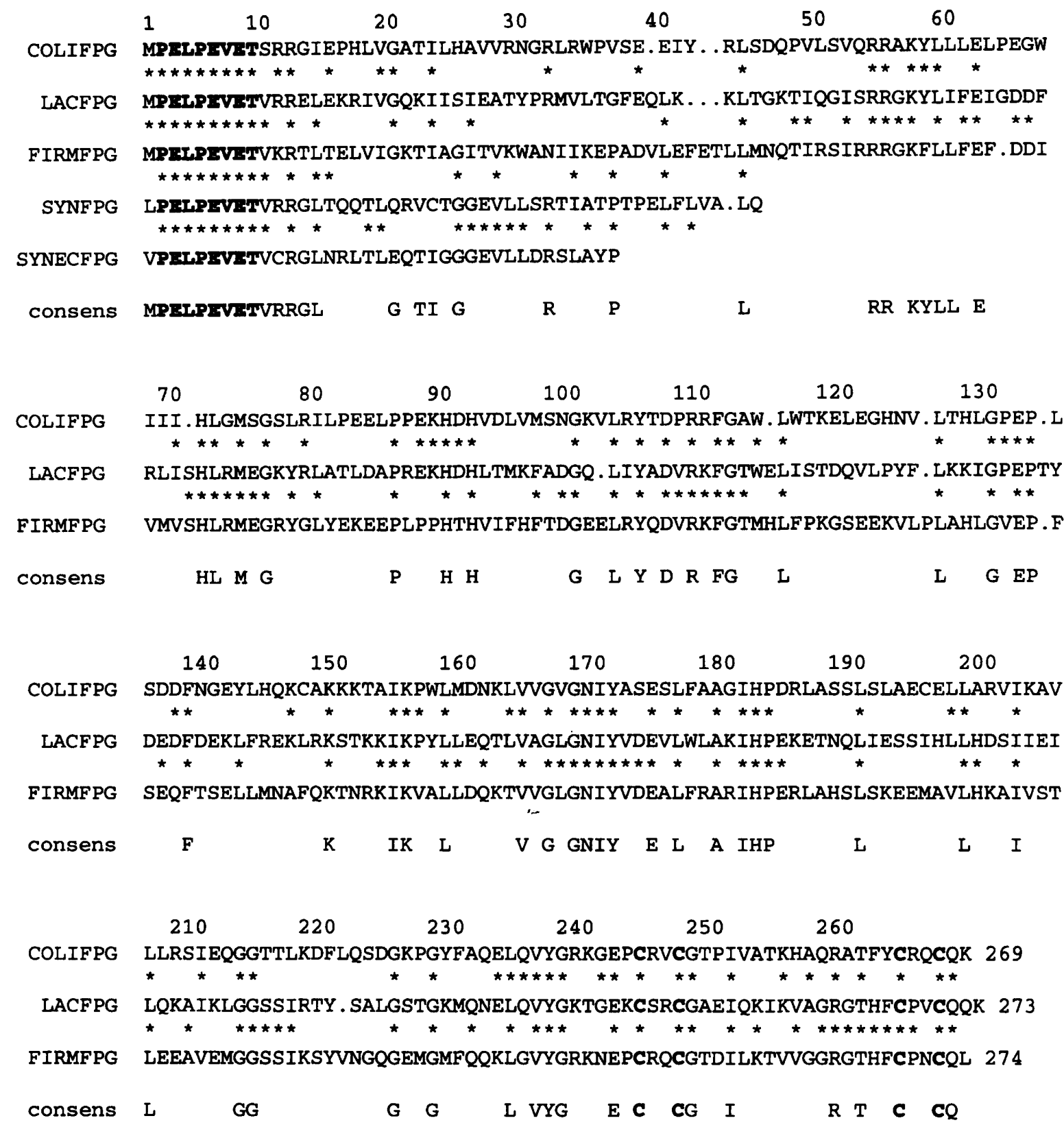

Fig. 2. Comparison of the deduced amino acid sequences of the fpg genes from $E$. coli (COLIFPG), L. lactis (LACFPG), Bacillus firmus (FIRMFPG), Synechococcus sp. (SYNFPG) and Synechocystis sp. (SYNECFPG). Amino acid positions correspond to the $E$. coli $\mathrm{Fpg}$ protein. A star indicates identity. An amino acid is shown in the consensus sequence (consens) if it is identical in at least three sequences. The amino acids in bold are discussed in the text.

activity are overexpressed in a crude lysate of IPTGinduced cells hosting plasmid pVE1064 (Table 1). Secondly, both activities copurify during all the purification steps and the ratio of these two activities remains constant (Table 1). The ability of the Fpg-L protein to repair 8-OxoG was studied using an oligonucleotide containing a single 8 -OxoG. The 8 -OxoG-containing strand was ${ }^{32} \mathrm{P}$ labelled and annealed with a complementary sequence possessing one of the four DNA bases opposite 8-OxoG. These duplexes were used as substrates for the Fpg-L protein (Fig. 5). The Fpg-L protein readily incises duplexes with cytosine, thymine or guanine opposite 8-OxoG (Fig. 5). In contrast, as with Fpg-E, the rate of incision of the duplex with adenine opposite 8-OxoG was much slower (Fig. 5). In all cases, the two fragments generated by Fpg-L were identical to those produced by Fpg-E. These results suggest that the mechanisms of incision at an AP site by Fpg-L and Fpg-E are identical (Bailly et al., 1989). The release of free 8-OxoG, due to DNA glycosylase activity of the Fpg-L protein, was directly confirmed by HPLC analysis of the reaction products (data not shown). 
Table 1. Purification of the Fpg-L protein from $13 \mathrm{~g}$ IPTG-induced E. coli BH410(pVE1064)

Fapy DNA glycosylase and AP site nicking activities were measured using $\left[{ }^{3} \mathrm{H}\right]$ Fapy-poly $(\mathrm{dG}-\mathrm{dC})$ and partially depurinated $\left[{ }^{3} \mathrm{H}\right]$ thymine DNA as substrate, respectively (Boiteux et al., 1984, 1990b). Control IPTG-induced BH410(pBS) crude extract had no detectable Fapy DNA glycosylase activity and $0.6 \mathrm{kU} \mathrm{mg}^{-1}$ of AP site nicking activity.

\begin{tabular}{|c|c|c|c|c|}
\hline Step & $\begin{array}{c}\text { Protein } \\
\text { (mg) }\end{array}$ & $\begin{array}{c}\text { Fapy DNA } \\
\text { glycosylase } \\
\text { activity } \\
\left(\mathbf{k U ~ ~ ^ { - 1 } )}\right.\end{array}$ & 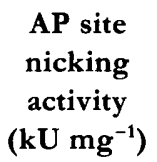 & $\mathbf{R}^{*}$ \\
\hline 1 & 1946 & $2 \cdot 1$ & $30 \cdot 6$ & 15 \\
\hline 2 & 1860 & $2 \cdot 3$ & $32 \cdot 3$ & 14 \\
\hline 3 & 74 & $39 \cdot 9$ & $529 \cdot 1$ & 13 \\
\hline 4 & 28 & $55 \cdot 3$ & $835 \cdot 7$ & 15 \\
\hline 5 & 14 & 103.9 & $1600 \cdot 1$ & 15 \\
\hline 6 & 12 & $108 \cdot 2$ & $1687 \cdot 5$ & 16 \\
\hline
\end{tabular}

* R, AP site nicking activity/Fapy DNA glycosylase activity.

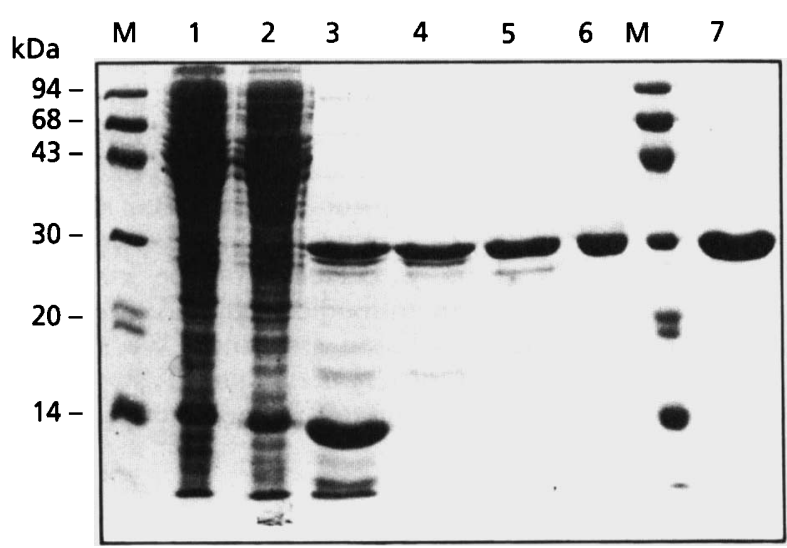

Fig. 3. SDS-PAGE analysis of the Fpg-L protein purification fractions. Lane $M$, molecular mass markers, phosphorylase $b$ $(94 \mathrm{kDa}), \mathrm{BSA}(68 \mathrm{kDa})$, ovalbumin $(43 \mathrm{kDa})$, carbonic anhydrase (30 kDa), trypsin inhibitor (20 kDa) and B-lactalbumin (14 kDa). Lanes 1-6 correspond to the different purification steps described in Table 1 and in Methods. PAGE was performed using $15 \%(\mathrm{w} / \mathrm{v})$ polyacrylamide gel. The amounts of Fpg-L protein loaded on the gel were: lanes 1 and 2, $50 \mu \mathrm{g}$; lane 3, $10 \mu \mathrm{g}$; lanes 4,5 and $6,5 \mu \mathrm{g}$. Lane $7,5 \mu \mathrm{g}$ purified $\mathrm{Fpg}-\mathrm{E}$ protein.

\section{Biological function of the Fpg-L protein}

To investigate the biological role of the Fpg-L protein, we analysed its capacity to suppress the spontaneous mutator phenotype of $f p g$ and mut $Y$ mutants of E. coli. The E. coli strains used were derived from CC104, which has a lac $Z$ mutation that can only revert through a $\mathrm{GC} \rightarrow \mathrm{TA}$ transversion event (Cupples \& Miller, 1989). Wild-type, $f p g$ or mut $Y$ single mutants, and an $f p g$ mut $Y$ double mutant were transformed with pVE1064, which contains a functional $f p g-\mathrm{L}$ gene under the control of the lac promoter. Table 2 shows that the presence of the

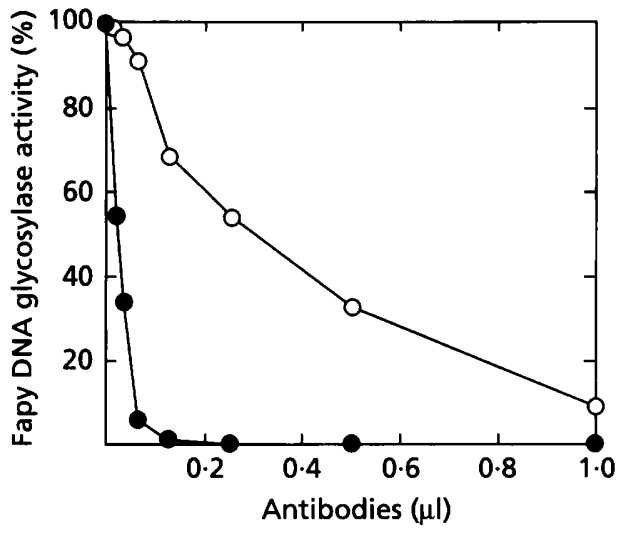

Fig. 4. Inhibition of Fpg-L and Fpg-E proteins by antibodies against Fpg-E protein. Inhibition of the Fapy DNA glycosylase activity of Fpg-L $(O)$ and Fpg-E (O) proteins by antibodies against Fpg-E protein. Residual activity was expressed as percentage of control activity without antibodies. Up to $2 \mathrm{ml}$ preimmune serum had no detectable inhibitory effect.

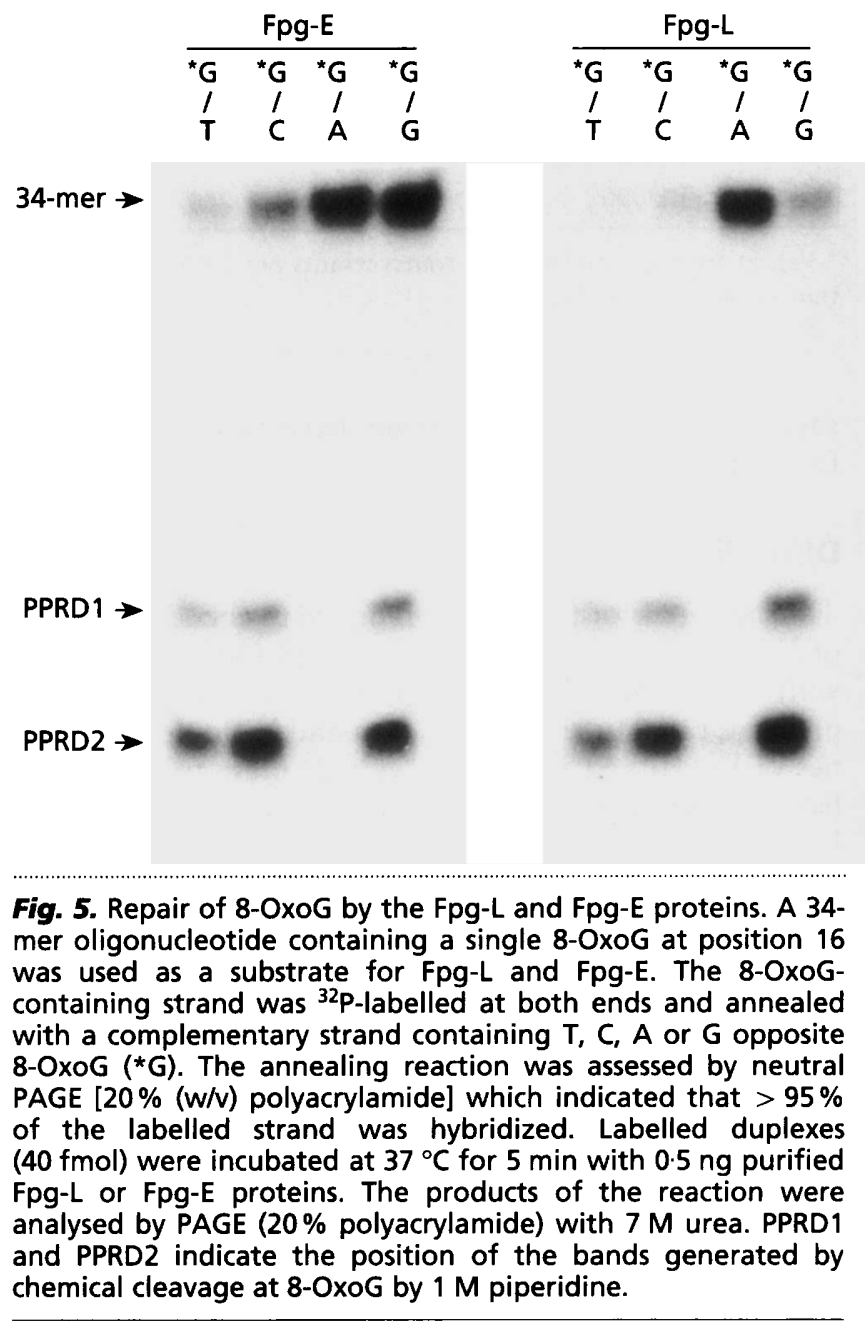

Fpg-L protein greatly reduces spontaneous mutagenesis in $f p g, m u t Y$ and $f p g$ mut $Y$ strains of $E$. coli. The fact that the Fpg-L protein can substitute for the E. coli enzyme 
Table 2. Spontaneous GC $\rightarrow$ TA mutagenesis in $f p g$ and mutY mutants of $E$. coli expressing the $f p g$ - $L$ gene from plasmid pVE1064

Five or more independent overnight cultures of $E$. coli hosting pVE1064 or pBS (the vector from which pVE1064 was derived) were grown in LB broth containing ampicillin. Aliquots were plated on LB agar containing ampicillin $\left(100 \mu \mathrm{g} \mathrm{ml}^{-1}\right)$ and rifampicin $\left(100 \mu \mathrm{g} \mathrm{ml}^{-1}\right)$ or on minimal glucose or minimal lactose plates containing ampicillin only (Cupples \& Miller, 1989).

\begin{tabular}{|c|c|c|}
\hline \multirow[t]{2}{*}{ Bacterial strain } & \multicolumn{2}{|c|}{$\begin{array}{c}\text { Frequency of } \\
\text { GC } \rightarrow \text { TA } \\
\text { transversion* }\end{array}$} \\
\hline & $\mathbf{R i f}^{\mathrm{R}}$ & $\mathbf{L a c}^{+}$ \\
\hline \multicolumn{3}{|l|}{ Hosting pBS: } \\
\hline CC104 (wild-type) & 5 & 2 \\
\hline $\mathrm{BH} 540(f p g)$ & 19 & 44 \\
\hline BH $980(m u t Y)$ & 162 & 480 \\
\hline BH990 (fpg mut $Y)$ & 1651 & 13530 \\
\hline \multicolumn{3}{|l|}{ Hosting pVE1064: } \\
\hline CC104 (wild-type) & 4 & 3 \\
\hline BH540 $(f p g)$ & 5 & 6 \\
\hline $\mathrm{BH} 980(m u t Y)$ & 34 & 86 \\
\hline BH 990 (fpg mut $Y)$ & 84 & 280 \\
\hline
\end{tabular}

* Values are expressed as Rif $^{\mathrm{R}}$ transversants per $10^{8}$ cells and $\mathrm{Lac}^{+}$ transversants per $10^{9}$ cells.

suggests that these two proteins have similar biological function.

\section{DISCUSSION}

The $f p g$ - $\mathrm{L}$ gene of $L$. lactis is predicted to encode a protein of 273 amino acids with $59 \%$ similarity and $38 \%$ identity with the E. coli Fpg protein, Fpg-E. Comparison of physical, catalytic, immunological and biological properties of Fpg-L and Fpg-E shows that these two proteins have highly conserved structure and function. Both Fpg-L and Fpg-E are monomeric proteins which possess both a DNA glycosylase activity and another activity that nicks DNA at AP sites. Both enzymes are metalloproteins with one zinc per molecule, and they possess a zinc finger consensus sequence at the carboxy-terminal end. Both proteins protect DNA against the mutagenic action of oxidized purines.

In $E$. coli, the $f p g$ and $\operatorname{rec} A$ genes are not linked (Boiteux \& Huisman, 1989), and fpg expression is not altered by known DNA-damaging agents. In L. lactis, the $f p g$ gene may have some other important functions. During transcription analysis of the $f p g$-L gene, we identified only an fpg-rec $A$ cotranscript (Duwat et al., 1994), and attempts to identify an $f p g$ mRNA were unsuccessful (data not shown). Furthermore, we observed that the lactococcal $\operatorname{rec} A$ strain is oxygen-sensitive (Duwat et al., 1994). These data led us to ask whether there may be an interaction between the SOS-like pathway and the GO system. The recent isolation of an $L$. lactis $f p g$ mutant may help us to understand the real function of the gene and the possible links between the different repair pathways.

Our results imply that the fpg gene from the Grampositive bacterium $L$. lactis and the Gram-negative bacterium $E$. coli have issued from a common ancestor. Boiteux et al. (1990a) suggested the presence of Fpg proteins in other bacteria including Salmonella typhimurium, Micrococcus luteus, Bacillus subtilis, and our results suggest the presence of Fpg proteins in B. firmus, Synechocystis sp. and Synechococcus sp. The conservation of the Fpg protein in evolutionarily distant bacteria suggests that this protein plays an important role in cellular defence against free radicals and ROS attack on DNA in prokaryotic cells.

\section{ACKNOWLEDGEMENTS}

The authors gratefully acknowledge support from CNRS, the Association pour la Recherche contre le Cancer; and the European Community (grants EV5V-CT92-0223 and BiotCT91.0263). R.O. was supported by a fellowship from the Fondation pour la Recherche Médicale. We thank Drs P. Radicella (MIT, Boston, USA), J. H. Miller (University of California, Los Angeles, USA) and P. Nehls (Institute for Cell Biology, Essen, Germany) for their kind gifts of bacterial strains and modified oligonucleotide. We thank Dr A. Gouyette (IGR, Villejuif, France) for measuring the zinc content of the Fpg-L protein and Dr J. P. LeCaer (Institut A. Fessard, Gif sur Yvette, France) for determining the amino-terminal sequence of the Fpg-L protein. We thank C. D'Herin for the kind gift of purified anti-Fpg-E protein antibodies and $P$. Auffret van der Kemp for her excellent technical assistance. We thank Drs C. Anagnostopoulos, A. Gruss, J. Laval and T. R. O'Connor for discussion and critical reading of the manuscript.

\section{REFERENCES}

Ames, B. N., Shinegawa, M. K. \& Hagen, T. M. (1993). Oxidants, antioxidants, and the degenerative diseases of aging. Proc Natl Acad Sci US A 90, 7915-7922.

Bailly, V., Verly, W. G., O'Connor, T. R. \& Laval, J. (1989). Mechanism of DNA strand nicking at apurinic/apyrimidinic sites by Escherichia coli formamidopyrimidine DNA glycosylase. Biochem J 262, 581-589.

Boiteux, S. (1993). Properties and biological functions of the NTH and FPG proteins: two DNA glycosylases that repair oxidative damage in DNA. Photochem Photobiol B 19, 87-96.

Boiteux, S. \& Huisman, O. (1989). Isolation of a formamidopyrimidine DNA glycosylase ( $f p g$ ) mutant of Escherichia coli K12. Mol \& Gen Genet 215, 300-305.

Boiteux, S., Belleney, J., Roques, B. P. \& Laval, J. (1984). Two rotameric forms of open-ring 7-methylguanine are present in alkylated polynucleotides. Nucleic Acids Res 12, 5429-5439.

Boiteux, S., O'Connor, T.R. \& Laval, J. (1987). Formamidopyrimidine DNA glycosylase of E. coli: cloning and sequencing of the $f p g$ structural gene and overproduction of the protein. EMBO J 6, 3177-3183.

Boiteux, S., Lemaire, M. A. \& Laval, J. (1990a). Conservation of formamidopyrimidine DNA glycosylase activity in prokaryotes. In Ionizing Radiation Damage to DNA: Molecular Aspects, pp. 89-96. Edited by S. S. Wallace \& R. B. Painter. 
Boiteux, S., O'Connor, T. R., Lederer, F., Gouyette, A. \& Laval, J. (1990b). Homogeneous Escherichia coli FPG protein. J Biol Chem 265, 3916-3922.

Boiteux, S., Gajewski, E., Laval, J. \& Dizdaroglu, M. (1992). Substrate specificity of the Escherichia coli Fpg protein: excision of purine lesion in DNA produced by ionizing radiation and photosensitization. Biochemistry 31, 106-110.

Breimer, L. H. (1984). Enzymatic excision from $\gamma$-irradiated polynucleotides of adenine residues whose imidazole ring have been ruptured. Nucleic Acids Res 12, 6359-6367.

Breimer, L. H. (1990). Molecular mechanisms of oxygen radical carcinogenesis and mutagenesis: the role of DNA base damage. Mol Carcinog 3, 188-197.

Breimer, L. H. \& Lindahl, T. (1985). Thymine lesions produced by ionizing radiation in double stranded DNA. Biochemisiry 24, 4018-4022.

Castaing, B., Geiger, A., Seliger, H., Nehls, P., Laval, J., Zelwer, C. \& Boiteux, S. (1993). Cleavage and binding of a DNA fragment containing a single 8-oxoguanine by wild type and mutant FPG proteins. Nucleic Acids Res 21, 2899-2905.

Chetsanga, C. J. \& Lindahl, T. (1979). Release of N7-methylguanine residues whose imidazole ring have been opened from damaged DNA by a DNA glycosylase from Escherichia coli. Nucleic Acids Res 6, 3673-3684.

Chitnis, P. R., Reilly, P. A., Miedel, M. C. \& Nelson, N. (1989). Structure and mutagenesis of the gene encoding $8-\mathrm{kDa}$ subunit of photosystem I from the cyanobacterium Synechocystis sp. PCC 6803. J Biol Chem 264, 18374-18380.

Cupples, C. G. \& Miller, J. H. (1989). A set of lac $Z$ mutations in Escherichia coli that allow rapid detection of the six base substitutions. Proc Natl Acad Sci US A 86, 5345-5349.

Czeczot, H., Tudek, B., Lambert, B., Laval, J. \& Boiteux, S. (1991). Escherichia coli Fpg protein and UvrABC endonuclease repair DNA damage induced by methylene blue plus visible light in vivo and in vitro. J Bacteriol 173, 3419-3424.

Dizdaroglu, M. (1991). Chemical determination of free-radical induced damage to DNA. Free Radical Biol \& Med 10, 225-242.

Dizdaroglu, M., Laval, J. \& Boiteux, S. (1993). Substrate specificity of the E. coli endonuclease III : excision of thymine and cytosine derived lesions in DNA produced by radiation-generated free radicals. Biochemistry 32, 12105-12111.

Duwat, P., Ehrlich, S. D. \& Gruss, A. (1992). Use of degenerate primers for polymerase chain reaction cloning and sequencing of the Lactococcus lactis subsp. lactis recA gene. Applied Environ Microbiol 58, 2674-2678.

Duwat, P., Sourice, S., Ehrlich, S. D. \& Gruss, A. (1994). recA gene involvement in oxidative and thermal stress in Lactococcus lactis. In Genetics of Streptococci, Enterococci, and Lactococci. Edited by J. J. Ferretti (in press).

Graves, R. J., Felzenswalb, I., Laval, J. \& O'Connor, T. R. (1992). Excision of $5^{\prime}$-terminal deoxyribose phosphate from damaged
DNA is catalysed by the Fpg protein of E. coli. J Biol Chem 267, 14429-14435.

Grollman, A. P. \& Moriya, M. (1993). Mutagenesis by 8 oxoguanine: an enemy within. Trends Genet 9, 246-249.

Ivey, D. M. (1990). Nucleotide sequence of a gene from alkaliphilic Bacillus firmus $\mathrm{RAB}$ that is homologous to the $f p g$ gene of $E$. coli. Nucleic Acids Res 18, 5882.

LeBourgeois, P., Mata, M. \& Rizenthaler, P. (1992). Genome comparison of Lactococcus strains by pulsed-field electrophoresis. FEMS Microbiol Lett 55, 65-70.

Lin, J. J. \& Sancar, A. (1989). A new mechanism for repairing oxidative damage to DNA: (A)BC excinuclease removes AP sites and thymine glycols from DNA. Biochemistry 28, 7979-7984.

Michaels, L. M. \& Miller, J. H. (1992). The GO system protects organisms from the mutagenic effect of the spontaneous lesion 8-hydroxyguanine (7,8-dihydro-8-oxoguanine). $J$ Bacteriol 174, 6321-6325.

Michaels, L. M., Cruz, C., Grollmann, A. P. \& Miller, J. H. (1992). Evidence that MutY and MutM combine to prevent mutation by an oxidative damaged form of guanine. Proc Natl Acad Sci USA 89, $7022-7025$.

Miller, J. H. (1972). Experiments in Molecular Genetics. Cold Spring Harbor, NY: Cold Spring Harbor Laboratory.

O'Connor, T. R., Graves, R. J., deMurcia, G., Castaing, B. \& Laval, J. (1993). Fpg protein of Escherichia coli is a zinc finger protein whose cysteine residues have a structural and/or functional role. $J$ Biol Chem 268, 9063-9070.

Radicella, P., Clarck, E. A. \& Fox, M. S. (1988). Some mismatch repair activities in Escherichia coli. Proc Natl Acad Sci USA 85, 9674-9678.

Rhiel, E. \& Bryant, D. A. (1992). GenBank data base, accession number JO5079.

Sambrook, J., Fritsch, E. F. \& Maniatis, T. (1989). Molecular Cloning: a Laboratory Manual, 2nd edn. Cold Spring Harbor, NY: Cold Spring Harbor Laboratory.

Sancar, A. \& Myles, G. M. (1989). DNA repair. Chem Res Toxicol2, 197-226.

Tchou, J., Kasai, H., Shibutani, S., Chung, M. H., Laval, J., Grollman, A.P. \& Nishimura, S. (1991). 8-Oxoguanine (8hydroxyguanine) DNA glycosylase and its substrate specificity. Proc Natl Acad Sci US A 88, 4690-4694.

Terzaghi, B. E. \& Sandine, W. E. (1975). Improved medium for lactic streptococci and their bacteriophages. Appl Microbiol 29, 807-813.

Tudek, B., Laval, J. \& Boiteux, S. (1993). SOS independent mutagenesis in lac $Z$ induced by methylene blue plus visible-light. Mol \& Gen Genet 236, 433-439.

Received 11 July 1994; revised 19 September 1994; accepted 13 October 1994. 